\title{
MYOCARDIAL DAMAGE IN CORONARY ARTERY BYPASS SURGICAL PATIENTS ANAESTHETIZED WITH TWO ANAESTHETIC TECHNIQUES: A RANDOM COMPARISON OF HALOTHANE AND ENFLURANE
}

\author{
J.G. Reves. Paul N. Samuelson, William A. Lell. Huey G. McDaniel, Nicholas T. \\ Kouchoukos, William J. Rogers, Lloyd R. Smith and Michael R. Carter
}

\section{A GSTRACT}

Fifty patients with ischaemic heart discase scheduled for coronary artery bypass surgery received either an enflurane or a halothane anaesthetic. The anaesthetic techniques were randomly assigned to the patients and consisted of induction with diazepam $0.5 \mathrm{mg} \cdot \mathrm{kg}^{-1}$ and pancuronium $0.1 \mathrm{mg} \cdot \mathrm{kg}^{-1}$ supplemented by nitrous oxide and oxygen (50:50). Enflurane in dosages of $0.5-1.5$ volumes per cent and halothane $0.3-0.7$ volumes per cent were administered to Group E (25 patients) and Group $\mathrm{H}$ (25 patients), respectively. The inhalation drug dosage was varied to maintain heart rate and systemic blood pressure within predetermined limits.

The two patient groups ( $E$ and $\mathrm{H}$ ) were compared with regard to myocardial damage (determined electrocardiographically and enzymatically) as well as by haemodynamic changes and adjuvant cardiovascular drug therapy. One patient in group $\mathrm{H}$ sustained a postoperative infarction detected by electrocardiogram and sustained CK MB release. There was no other unequivocal electrocardiographic evidence of myocardial infaretion in either group and the myocardial damage estimated from CK MB curves was remarkably low and similar in both anaesthetic groups. Myocardial damage was estimated by $\mathrm{CK} M B$ maximum release (CK MB MAX) of $8.1 \pm 1.00 \mathrm{IU} / \mathrm{l}$ (Group E), $7.8 \pm 1.32 \mathrm{IU} / \mathrm{l}(\mathrm{Group} \mathrm{H})$, by area under the CK MB disappearance curve (CK MB AREA) of $144 \pm 21.9 \mathrm{IU} / 1 \times \mathrm{hr}$ (Group E), $173 \pm$ $32.9 \mathrm{IU} / \mathrm{l} \times \mathrm{hr}$ (Group $\mathrm{H}$ ), and by the accumulated CK MB or CK MB damage size (CK MB DS) of $10.5 \pm 1.79 \mathrm{IU} / \mathrm{l}$ (Group E), $10.3 \pm 2.26 \mathrm{IU} / \mathrm{I}$ (Group H). There was no release of CK MB before cardiopulmonary bypass in either group. There was no statistically significant difference between the two groups for myocardial damage, haemodynamics or adjuvant drug interventions. There was a trend toward greater use of vasodilators in Group $\mathrm{H}$ than in Group E.

It is concluded that enflurane and halothane are associated with equally low levels of myocardial damage when used for anaesthesia in patients with ischaemic heart disease. The release of CK MB occurred following cardiopulmonary bypass and probably represents imperfect myocardial preservation. Patients with severely impaired ventricularfunction were not studied, and in these patients enflurane and halothane must be used judiciously.

ANAESTHETIC MANAGEMENT using halothane, nitrous oxide and adjuvant agents for patients undergoing myocardial revascularization is associated with a low level of myocardial damage. ${ }^{1}$ The purpose of this prospective investigation was to determine the incidence and extent of myocardial damage associated with an enflurane technique compared to halothane. The specific question to be answered was whether the use of either

J.G. Reves, M.D., Professor of Anaesthesiology; Paul N. Samuelson, M.D., Associate Professor of Anaesthesiology; William A. Lell, M.D., Professor of Anaesthesiology; Huey G. McDaniel, M.D., Associate Professor of Medicine; Nicholas T. Kouchoukos, M.D., Professor of Surgery; William J. Rogers, M.D., Assistant Professor of Medicine; Lloyd R. Smith. M.A., Data Manager, Clinical Cardiovascular Computer Center; Michael R. Carter, C.P.T., Research Assistant, The University of Alabama Medical Center, Birmingham, Alabama 35294.

A portion of the study was funded by Ohio Medical products. halothane or enflurane as a component of an otherwise similar anaesthetic treatment plan results in less myocardial damage. Since enflurane is similar in its pharmacological actions to halothane, enflurane was chosen for comparison with the previously established' low levels of myocardial damage associated with halothane.

\section{METHODS}

Fifty patients of a single surgeon scheduled for elective myocardial revascularization were randomized to two groups of 25 patients each receiving either enfurane (Group E) or halothane (Group $\mathrm{H}$ ) as the primary anaesthetic agent.* The anaesthetic techniques were similar in all other regards. All patients were premedicated $60-90$

* This investigation was approved by the Institutional Review Board of the University of Alabama in Birmingham. 


\section{TABLE I}

Criteria for Pharmacological Interventions During the Anaesthetic Management of 50 Coronary Artery Surgery Patients

If: $\mathrm{BP}>30$ per cent control for 5 minutes

Then: $\uparrow$ halothane or enflurane \pm vasodilator

If: $\mathrm{BP}<30$ per cent control for 5 minutes

Then: $\downarrow$ halothane or enflurane, $\uparrow$ fluid, \pm vasopressor:

lf: $H R>120$ for 5 minutes

Then: $\uparrow$ halothane or enflurane \pm propranolol (0.5-1 mg)

If: $\mathrm{HR}<50$ for 5 minutes

Then: atropine $(0.6-0.8 \mathrm{mg})$

If: Arrhythmias

Then: appropriate anti-arrhythmic of choice

Where: $\pm=$ optional use of drug: vasodilator $=$ nitroprusside $\left(50 \mathrm{mg} / 250 \mathrm{ml} \mathrm{D}_{5} \mathrm{~W}\right)$ usual dose $1-5 \mu \mathrm{g} \cdot \mathrm{kg}^{-1} / \mathrm{min}$ administered intravenously with infusion pump, or nitroglycerin (10 tablets, $0.4 \mathrm{mg}$, dissolved in $10 \mathrm{ml}$ water) administered sublingually in $1.0 \mathrm{ml}$ increments, vasopressor-methoxamine or ephedrine and anti-arrhythmic = lidocaine given $1.0 \mathrm{mg} \cdot \mathrm{kg}^{-1}$ increments or propranolol given $0.5-1.0 \mathrm{mg}$ increments.

minutes before induction of anaesthesia with diazepam $0.15 \mathrm{mg} \cdot \mathrm{kg}^{-1}$ by mouth, morphine sulphate $0.1 \mathrm{mg} \cdot \mathrm{kg}^{-1}$ and scopolamine $0.3-0.4$ $\mathrm{mg}$ intramuscularly. Anaesthesia was induced with diazepam $0.5 \mathrm{mg} \cdot \mathrm{kg}^{-1}$ and pancuronium $0.1 \mathrm{mg} \cdot \mathrm{kg}^{-1}$ intravenously while the patient received nitrous oxide and oxygen 50:50. During induction, Group $E$ patients received enflurane $0.5-1.5$ volumes per cent inspired concentration and Group $\mathrm{H}$, halothane $0.3-0.7$ volumes per cent. Five minutes after induction, orotracheal intubation was done following a $160 \mathrm{mg}$ bolus of intra-tracheal lidocaine. Anaesthesia was maintained by adjusting the inspired concentration of inhalation anaesthetic or by administering adjuvant drugs to keep the heart rate and blood pressure within the limits shown in Table I. All vaporizers were recently calibrated. Myocardial preservation during cardiopulmonary bypass consisted of perfusate and intrapericardial cooling as well as aortic root infusion of cold potassium cardioplegic solution to maintain myocardial temperature below $18^{\circ} \mathrm{C}$ and electromechanical quiescence as previously described. ${ }^{2}$ The time that the ascending aorta was clamped to isolate the heart from circulation was defined as ischaemic time and the time of extracorporeal circulation was the bypass time.
CK-MB INFARCT SIZE ESTIMATION FROM CK-MB ALGORITHM
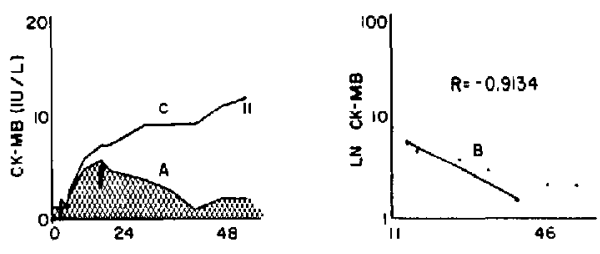

HOURS AFTER STARTING BYPASS

Figure I Picloral presentation of myocardial damage size estimation from $\mathrm{CK} M B$ algorithm from a patient anaesthetized with halothane for coronary bypass surgery. The left illustration (Curve A) is constructed from serial determinations of CK MB. The arrow points to the peak rise (CK MB MAX) in CK MB. The crosshatched area under Curve $A$ represents the $C K M B$ AREA. Curve $C$ describes the cumulative $C K$ MB released into plasma from the equation $\int_{0}^{1}\left(\mathrm{dE} / \mathrm{dt}-K_{0} E\right)$ dt. Curve $C$ is CK MB damage size (CK MB DS). The estimates of myocardial damage described in this work derived from the $C K M B$ data are $C K M B M A X, C K$ MB AREA, and CK MB DS. The right illustration contains a semi-log plot (Line B) of the plasma disappearance of CK MB. The correlation coefficient $(R)$ is 0.91 for the least squares fit in this patient, but was in excess of 0.95 for most patients. From Line B, a decay constant $\left(K_{D}\right)$ is derived and used in the calculation of the cumulative CK MB (see equation above).

Anacsthesia was maintained during cardiopulmonary bypass with diazepam $0.15 \mathrm{mg} \cdot \mathrm{kg}^{-1}$ and pancuronium $0.1 \mathrm{mg} \cdot \mathrm{kg}^{-1}$.

Monitoring included $\mathrm{V}_{5}$ electrocardiogram, radial arterial blood pressure (BP), central venous pressure (CVP) after induction and left atrial pressure (LAP) after sternotomy. These variables were monitored continuously and recorded on a Hewlett-Packard recorder. The zenith or nadir of haemodynamic fluctuations during tracheal intubation, preparation of the patient. sternotomy, just after placement of the left atrial pressure catheter, after protamine, and at the end of anaesthesia were compared. Conventional electrocardiogram analysis and serial identification and quantification of the myocardial specific isoenzyme, creatine phosphokinase MB fraction (CK MB) were used to assess myocardial damage. In all patients daily 12 lead electrocardiograms were obtained postoperatively and read by a single observer for QRS and ST segment changes indicative of infarction. The CK MB was separated from plasma by column chromatography and its activity was determined by a method previously described. ${ }^{3}$ Sampling occurred before induction, immediately before bypass and at $0.5,1,2,6,10,12,18,30,42,54$, 
TABLE II

Characteristics of Patients Randomized to Enflurane or Halothane for ANAESTHESIA DURINg CORONARY ARTERY SURgery

\begin{tabular}{|c|c|c|c|}
\hline & Enflurane & Halothane & $\mathrm{P}$ \\
\hline $\begin{array}{l}\text { Number patients } \\
\text { Age (years) } \\
\text { Sex } \\
\text { BSA }\left(\mathrm{m}^{2}\right)\end{array}$ & $\begin{array}{c}25 \\
53 \pm 2.1 \\
24-\mathrm{M}, 1-\mathrm{F} \\
1.97 \pm .038\end{array}$ & $\begin{array}{c}25 \\
53 \pm 1.7 \\
18-\mathrm{M}, 7-\mathrm{F} \\
1.86 \pm .045\end{array}$ & $\begin{array}{l}\text { NS } \\
\text { NS } \\
\text { NS } \\
.05\end{array}$ \\
\hline $\begin{array}{l}\text { CAD } \\
\text { LM } \\
\text { CX } \\
\text { LAD } \\
\text { R }\end{array}$ & $\begin{array}{r}2 \\
25 \\
25 \\
24\end{array}$ & $\begin{array}{r}3 \\
19 \\
24 \\
24\end{array}$ & $\begin{array}{l}\text { NS } \\
\text { NS } \\
\text { NS } \\
\text { NS }\end{array}$ \\
\hline $\begin{array}{l}\text { Previous infarction } \\
\text { NYHA } \\
\text { Yentricular function: } \\
\text { Normal } \\
\text { Mild dysfunction } \\
\text { Moderate dysfunction } \\
\text { Severe dysfunction }\end{array}$ & $\begin{array}{c}16 \\
2.6 \pm .13 \\
7 \\
14 \\
3 \\
1\end{array}$ & $\begin{array}{c}18 \\
2.8 \pm 2.0 \\
6 \\
12 \\
6 \\
1\end{array}$ & $\begin{array}{l}\text { NS } \\
\text { NS } \\
\text { NS } \\
\text { NS }\end{array}$ \\
\hline $\begin{array}{l}\text { Number CABG } \\
\text { Fib. temp }\left({ }^{\circ} \mathrm{C}\right) \\
\text { Ischaemic time (min) } \\
\text { Bypass time (min) } \\
\text { Anesthesia time (min) }\end{array}$ & $\begin{array}{r}3.8 \pm .19 \\
26 \pm 2.8 \\
41 \pm 1.8 \\
76 \pm 2.3 \\
257 \pm 6.3\end{array}$ & $\begin{aligned} 3.3 & \pm .21 \\
27 & \pm .6 \\
37 & \pm 2.7 \\
73 & \pm 5.6 \\
253 & \pm 10.1\end{aligned}$ & $\begin{array}{l}\text { NS } \\
\text { NS } \\
\text { NS } \\
\text { NS } \\
\text { NS }\end{array}$ \\
\hline
\end{tabular}

Where: $\mathrm{BSA}=$ body surface area, $\mathrm{CAD}=$ coronary artery disease involving: $\mathrm{LM}=$ left main, $\mathrm{CX}=$ circumflex, $\mathrm{LAD}=$ left anterior descending, $\mathrm{R}=$ right, NYHA = New York Heart Association functional classification. Ventricular dysfunction: Mild = one area of akinesis, hypo-kinesis or dyskinesis, Moderate $=$ two areas and Severe $=$ three or more areas. Fib. temp $=$ myocardial temperature at which heart fibrillates with perfusate cooling. Ischaemic time $=$ time of aortic crossclamping. Bypass time $=$ time of extracorporeal circulation.

and 66 hours after start of cardiopulmonary bypass. Estimates of myocardial damage were made from the individual CK MB disappearance curves with the aid of an IBM 1800 computer. ${ }^{3}$ Accumulated CK MB for total estimation of myocardial damage size (CK MB DS) was expressed in IU/litre, area under the disappearance curve was calculated (CK MB AREA) and expressed in $I U / l \times h r$, and maximal amount released (CB MB MAX) was expressed as IU/I (Figure 1). These estimates of damage were correlated with each other as well as with ischaemic time and total bypass time.

Comparisons between the enflurane and halothane groups were done using multivariate analysis for continuous variables, and for discrete variables standard multivariate contingency table analysis (Chi-Square tests) was used. Spearman correlation coefficients were determined to correlate indices of myocardial damage with each other and with ischaemic and bypass time. All statistical computations were performed using $\mathrm{SAS}^{4}$ on an IBM/370.

\section{RESULTS}

Characteristics of the patient populations are listed in Table II. The two groups were similar with the exception of mean body surface area. Table III lists haemodynamic values in both groups at the selected time periods. There were no significant differences between the groups at any time interval. Group $\mathbf{H}$ tended to have a greater rise in heart rate and blood pressure during intubation. There was a greater haemodynamic response to incision and sternotomy in Group E patients than Group H. Both groups had significant, transient (1-3 min) increases in heart rate and blood pressure with tracheal intubation. No ST changes indicative of ischaemia were observed during these haemodynamic changes. There was no difference between groups in the incidence or severity of disturbances of cardiac rhythm. Atrial fibrillation occurred before bypass in three patients of Group E and in two paticnts of Group $\mathrm{H}$ and junctional rhythm occurred in one patient before and after bypass in each group. 


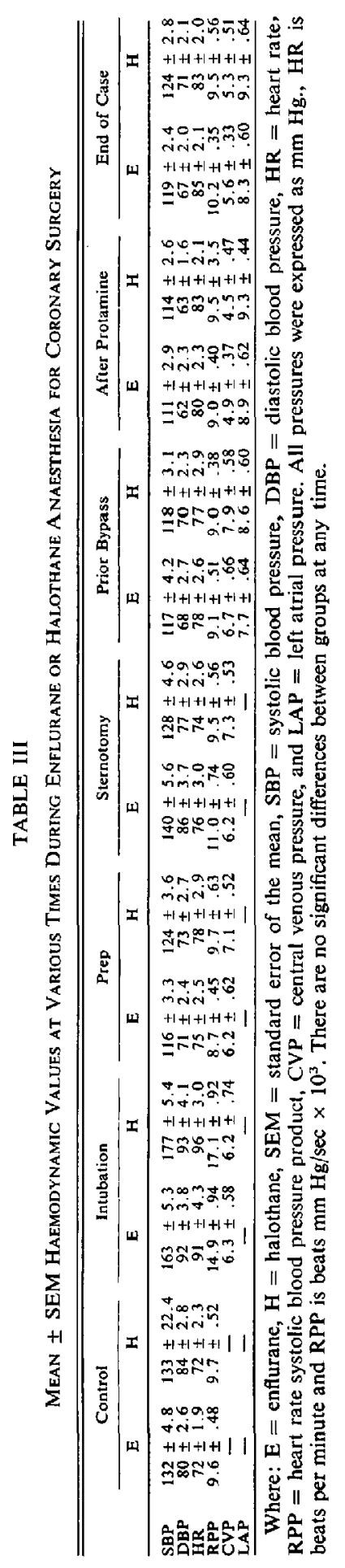


TABLE IV

Pharmacological Interventions Before and After ByPASS IN 50 PATIENTS ANAESTHETIZED WITH ENFluRane or Halothane for Coronary artery

$$
\text { SuRGERY }
$$

\begin{tabular}{cccccc}
\hline & \multicolumn{2}{c}{ Before Bypass } & & \multicolumn{2}{c}{ After Bypass } \\
\cline { 2 - 3 } \cline { 5 - 6 } & E & H & & E & H \\
\hline Vasodilator & 6 & 12 & & 5 \\
Nitroprusside & 5 & 3 & & 2 & 5 \\
Nitroglycerin & 1 & 7 & & 0 & 0 \\
Droperidol & 0 & 2 & & 0 & 0 \\
Inotropic & $1 /$ & 3 & & 14 & 6 \\
Calcium & 3 & 0 & & 9 & 5 \\
Ephedrine & 8 & 3 & & 5 & 1 \\
Vasoconstrictor & 1 & 0 & & 0 & 1 \\
Methoxamine & 1 & 0 & & 0 & 1 \\
Anti Arrhythmic & 3 & 1 & & 3 & 2 \\
Lidocaine & 1 & 1 & 2 & 2 \\
Propranolol & 2 & 0 & 1 & 0 \\
\hline
\end{tabular}

Where: Each number represents the number of patients in each group given the specific drug, $\mathrm{E}=$ enflurane technique $(\mathrm{N}=25)$ and $\mathrm{H}=$ halothane technique $(\mathrm{N}=25)$. None of the drug administrations differ significantly between groups.

\section{TABLE $V$}

Assessment of Myocardial Damage in Patients ANAESTHETIZED With ENFLURANe OR Halothane for CORONARY ARTERY SURGERY

\begin{tabular}{lrcrr}
\hline \hline & Enflurane & Halothane \\
\hline Enzyme Analysis & & & & \\
SGOT - PEAK & 75 & \pm 25.3 & 60 & \pm 12.2 \\
CKT MAX & 434 & \pm 9.1 & 403 & \pm 99.6 \\
CK MB MAX & $8.1 \pm 1.00$ & $7.8 \pm 1.32$ \\
CK MB area & $144 \pm \pm 21.9$ & 173 & \pm 32.9 \\
CK MB DS & $10.5 \pm 1.79$ & $10.3 \pm 2.26$ \\
ECG Analysis & & & \\
normal & 14 & 19 \\
equivocal & 11 & 5 \\
infarction & 0 & 1 \\
\hline
\end{tabular}

Where: SGOT - PEAK = peak values - occurred first post-op day, CKT-MAX = maximum total creatine phosphokinase value, CK MB MAX = maximum creatine phosphokinase-MB isoenzyme fraction, $\mathrm{CK} M \mathrm{M}$ arca = integrated area under the CK MB curve, CK MB DS = total accumulation of CK MB (estimate of "damage size"). No values or incidences are significantly different between groups. Units of measurement are listed in text. Data are arithmetic mean \pm S.E.M.

Lidocaine was used to treat premature ventricular contractions in one patient of each group before bypass and in two patients in each group after bypass.

The use of adjuvant cardiovascular drugs is

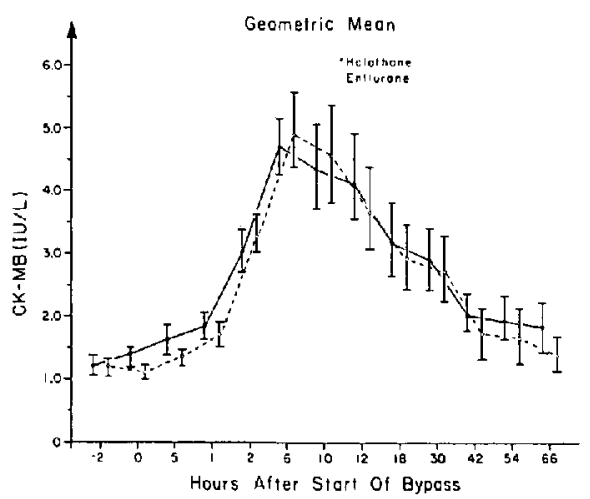

Figure 2 CK MB values for patients anaesthetized with either enflurane or halothane during and following myocardial revascularization surgery. The results are expressed as the geometric mean \pm standard error. There is no significant difference between values at any time.

presented in Table IV. There were no significant differences $(\mathrm{P}<0.05)$ in the requirements for these drugs, but a trend emerged toward greater use of vasodilators before bypass in Group $\mathrm{H}$ and more inotropic drugs before and after bypass in Group E. The vasodilator therapy was administered whenever criteria of Table II were violated and this was usually during surgical stimulation. One patient in Group E required a vasoconstrictor to correct hypotension before bypass.

Indices of myocardial damage are shown in Table $V$. There was no significant difference between groups with regard 10 enzymatic or electrocardiographic evidence of myocardial damage. Figure 2 illustrates the $\mathrm{CK} M B$ release for both groups. The control values and samples before cardiopulmonary bypass were normal* in both groups. The peak CK MB release (CK MB MAX) occurred at 6-10 hours after bypass and was $4.6 \pm 0.98 \mathrm{IU} / \mathrm{l}$ in Group $\mathrm{E}$ and $4.9 \pm 1.40 \mathrm{IU} / \mathrm{l}$ in Group H. One patient in Group H sustained an acute myocardial infarction after arriving in the intensive care unit. This patient had a peak total creatine phosphokinase (CKT MAX) of 1477 IU/I and CK MB MAX of $119 \mathrm{IU} / \mathrm{l}$ and was the only one who demonstrated unequivocal electrocardiographic changes indicative of a myocardial infarction. Table VI contains the Spearman correlation coefficients of the various estimates of myocardial damage with each other and with ischaemic time and bypass time. The poor correlation of indices of damage with ischaemic time and

${ }^{*}$ A value of 1-2 IU/litre is considered within the normal limits in our laboratory. 
TABLE VI

Spearman Correlation Coefficients for Estimates of Mrocakdial Damage and Bypass Times for 50 PATIENTS

\begin{tabular}{lcccc}
\hline \hline & CK MB MAX & CKT MAX & CK MB DS & CK MB area \\
\hline CK MB MAX & 1.000 & 0.547 & 0.834 & 0.848 \\
CKT MAX & 0.547 & 1.000 & 0.428 & 0.516 \\
CK MB DS & 0.834 & 0.428 & 1.000 & 0.779 \\
CK MB area & 0.848 & 0.516 & 0.779 & 1.000 \\
ISCHAEMIC t & 0.149 & $\mathrm{X}$ & 0.067 & 0.161 \\
BYPASS t & 0.162 & $\mathrm{X}$ & 0.122 & 0.164 \\
\hline
\end{tabular}

Where: $\mathrm{CK}$ MB MAX = maximum creatine phosphokinase $-\mathrm{MB}$ isoenzymc fraction, CKT MAX = maximum total creatine phosphokinase value, CK MB.DS = total accumulation of CK MB "Damage Size." CK MB area = integrated area under the CK MB curve, ISCHAEMIC $\mathrm{t}=$ time of aortic crossclamping, and BYPASS $\mathrm{t}=$ time of cardiopulmonary bypass, $\mathrm{X}=$ no data.

bypass time is of particular note. There is an excellent correlation of CK MB MAX with CK MB AREA and CK MB DS $(r=0.848$ and 0.834$)$, respectively.

\section{Discussion}

The goal of myocardial revascularization surgery is to establish blood flow to regions of the heart which have lost or are in jeopardy of losing adequate oxygen supply to match metabolic requirements. To preserve an adequate myocardial oxygen supply to demand relationship and to minimize myocardial damage are the challenges to the anaesthetist during the operation.

Myocardial damage following revascularization surgery has decreased due in part to notable advances in myocardial preservation during bypass. ${ }^{5.6}$ The overall role of anaesthetic treatment plans in minimizing myocardial damage remains controversial because of the lack of systematic studies examining this question. In the present study, we asked whether enflurane or halothane was superior in minimizing myocardial damage during the anaesthetic management of patients for revascularization surgery. To answer this question, enflurane and halothane techniques were randomly assigned to similar groups of patients given otherwise identical anaesthesia treatment. Vasoactive adjuvant drugs were used as required to stay within the predetermined haemodynamic criteria of Table $l$ if this could not be accomplished by manipulation of the inspired concentration of the inhalation anaesthetic. The results in Table $V$ clearly show that techniques utilizing enflurane and halothane resulted in minimal myocardial damage as documented by the level of CK MB and postoperative electro- cardiograms. Neither enflurane nor halothane was supcrior to the other with regard to minimizing myocardial damage.

Our clinical use of an anaesthetic technique which employs a combined use of inhalation and adjuvant agents for patients with ischaemic heart disease is the result of an evolutionary process from techniques first using ketamine, then morphine and now halothane or enflurane as the primary agent. ${ }^{7}$ Anaesthetic management for patients with ischaemic heart disease is designed to minimize changes in parameters that correlate with both myocardial oxygen consumption (heart rate, contractility, and wall tension) and oxygen supply (blood oxygen carrying capacity and coronary artery blood flow). ${ }^{7}$ To accomplish this, anaesthetic techniques by necessity involve the use of many drugs that decrease or maintain heart rate, wall tension and contractility, yet maintain or increase the oxygen carrying capacity (haemoglobin content and saturation) and myocardial blood flow (increased perfusion pressure and decreased coronary resistance, heart rate, and extravascular compression). The rationale for the use of halothane or enflurane is that they reduce myocardial oxygen consumption while preserving myocardial oxygen supply. In the normal dog, myocardial depression by both halothane and enflurane results in maintenance of normal myocardial metabolism..$^{8.9}$ There is conflicting evidence about halothane in conditions of myocardial ischaemia. Halothane diminishes ST segment evidence of myocardial ischaemia in the acutely ischaemic dog preparation: ${ }^{10}$ however, in a similar canine preparation we showed myocardial oxygen tension in the ischaemic region decreased after administration of halothane. ${ }^{11}$ Halothane also failed to prevent 
progression of myocardial damage in coronary artery ligation experiments in the rat. ${ }^{12}$ Application of these experimental findings to the clinical situation is impossible at this time, but it is interesting that improved epicardial ST changes with halothane (indicating less ischaemia) are not consistent with metabolic monitoring (i.e., decreased regional $\mathrm{PO}_{2}$ ) or histological studies ( $\mathrm{mi}$ croscopic extension of myocardial necrosis).

The haemodynamic changes of anaesthetic management regimens were examined at four clinically important pre-bypass stress periods: induction, tracheal intubation, during preparation of the patient and incision-sternotomy. During these times the greatest haemodynamic fluctuations occur and, therefore, myocardial oxygen supply and demand vary the most. The easily measured heart rate-systolic blood pressure product (RPP) is an excellent correlate of global myocardial oxygen consumption in awake ${ }^{13}$ and anaesthetized ${ }^{14}$ patients with ischaemic heart disease. Addition of the pulmonary artery wedge pressure measurement to RPP does not increase the correlation with myocardial oxygen consumption. ${ }^{13,14}$ In a previous randomized study of patients with ischaemic heart disease, we found the peak rise in RPP to occur during induction with ketamine and at incision or sternotomy with morphine. ${ }^{15}$ The haemodynamic findings with morphine have been confirmed recently in a similar study comparing morphine and halothane..$^{16}$ In the present study, the greatest RPP rise was at tracheal intubation. The significantly greater haemodynamic response to intubation than to incision in both Group $\mathrm{E}$ and $\mathrm{H}$ may be explained in two ways. First, it is unlikely that enough time (5-10 minutes after induction) had elapsed for either agent to have attained a level sufficient to prevent the haemodynamic response to intubation. Presumably a higher blood concentration had been attained by the time the incision was made 30 to 40 minutes after induction. Secondly, MAC is greater for tracheal intubation than for incision ${ }^{17}$ and, therefore, intubation represents a greater stimulation at a time when the blood, brain and myocardial blood levels of both enflurane and halothane were relatively lower than at incision.

The haemodynamic findings were predictable from previous comparative studies ${ }^{18}$ and the known similarity in the pharmacological actions of enflurane and halothane. ${ }^{19.20}$ The inhalation agents were used with a host of other anaesthetic drugs which are known to alter the myocardial oxygen supply/demand relationship in various ways, ${ }^{21}$ but the predominant anaesthetic in each group was either enflurane or halothane. These drugs are primarily myocardial depressants whose effects are dose related. ${ }^{22,23}$ End-tidal concentrations were not used because during the clinical course of anaesthetic management of patients with ischaemic heart disease frequent changes in the inhalation anaesthetic concentrations were required. Thus the probability of obtaining a valid (equilibrated) end-tidal anaes thetic concentration was remote. Only two of the 50 patients had severe left ventricular dysfunction and, therefore, the use of either enflurane or halothane in patients with ventricular dysfunction was not examined. The use of either should be judicious because of their potential for myocardial depression in this sub-group of patients.

Conventional electrocardiographic analyses and serial identification and quantification of the myocardial specific isoenzyme, CK MB, provided the means of evaluating the incidence and estimating the extent of myocardial damage associated with the two anaesthetic techniques. CK MB is one of the three isoenzymes of creatine phosphokinase. It is found predominately in myocardial tissue, but also in very small amounts in the lung. Release of CK MB into the blood is a highly specific and sensitive marker of myocardial cell damage ${ }^{24}$ and the $C K$ MB plasma decay curve (plasma clearance) correlates with estimates of myocardial damage (Figure 1 and Table V). ${ }^{3.24 .25}$ CK MB may be detected in plasma within 30 minutes of myocardial damage. Gray and co-workers measured CK MB in coronary sinus effluent at frequent intervals. ${ }^{26}$ This is not feasible in the routine clinical case, but probably would improve the sensitivity and indicate better the exact time when myocardial damage began. Significant release of CK MB before bypass in other studies ${ }^{26,27,28}$ demonstrated that this period during anaesthetic management is critical in patients with ischaemic heart disease. Undoubtedly interventions during the interval before cardiopulmonary bypass are important in protecting jeopardized myocardium. The overall low level and negligible pre-bypass amount of CK MB release in this study support this conclusion. Despite transient haemodynamic alterations, both anaesthetic techniques were effective in preventing myocardial damage during the prebypass interval. It is possible that periods of is. chaemia may have gone undetected by the elec. 
trocardiographic and enzymatic methods employed, but unlikely that significant myocardial damage occurred.

Two interesting facts emerge from Table VI, which correlates the indices of myocardial damage with other variables. First, the peak rise of CK MB, the CK MB MAX, occurring 6-10 hours after bypass (Figure 2), correlates well $(r=0.848)$ with the area under the CK MB disappearance curve. Thus, if an anaesthetist suspects that his patient (having any kind of surgery) may have suffered acute necrosis, he should sample the blood for CK MB activity 6-10 hours after the event to obtain a good estimate of the amount of myocardial damage. Secondly, since CK MB release followed cardiopulmonary bypass, it appears that damage occurs during cardiopulmonary bypass, presumably during ischaemic myocardial arrest or with reperfusion. Ischaemic time does not correlate $(r=0.067-0.161)$ with CK MB estimates of myocardial damage. This is a change from Lell's previous report which demonstrated a weak but significant $(P<0.04)$ correlation ( $r=0.3)$ of CK MB AREA with ischaemic time. ${ }^{1}$ That this correlation no longer exists together with the observation that CK MB release is less now following cardiopulmonary bypass than previously reported suggests that the current method of myocardial preservation has reduced the amount of myocardial damage sustained during cardiopulmonary bypass. The use of cold potassium cardioplegic solution in addition to perfusate and external myocardial cooling appear to be effective in minimizing myocardial damage during cardiopulmonary bypass as shown by the low levels of damage documented in this study. This supposition is further supported by the myocardial preservation study of Conti and colleagues which showed that cold cardioplegia provided better functional protection of the heart and caused less myocardial necrosis than did cold ischaemic arrest. ${ }^{2}$

Despite the low levels of myocardial damage reported in this paper, damage did occur, suggesting that there is still room for improvement in the management of these patients. Probably the greatest frustration in the anaesthetic management is not having a continuous monitor of regional myocardial oxygen supply and demand. Ischaemic heart disease is a regional myocardial discase and, as yet, there are no clinically available monitors of regional myocardial oxygen supply and demand. Monitoring currently used (e.g. RPP) indirectly reflects total or global myocardial oxygen consumption, ${ }^{13,14}$ not jeopardized regional myocardial oxygen consumption or oxygen supply. Use of the ratio of diastolic pressure time index to tension time index (DPTI/TTI) ${ }^{29}$ or its modification, the endocardial viability ratio (EVR) ${ }^{30}$ is inappropriate for monitoring regional flow in patients with coronary obstructive lesions, since subendocardial blood flow cannot be predicted because of the unknown fixed coronary artery resistance. ${ }^{31}$ The electrocardiogram is the only reliable method of detecting regional myocardial ischaemia, but it lacks sensitivity and specificity. ${ }^{31,32}$

\section{Conclusion}

During myocardial revascularization surgery, patients anaesthetized with halothane or enflurane techniques designed to keep the haemodynamics within pre-set bounds have minimal levels of myocardial damage as documented by CK MB. The damage to the myocardium apparently occurs during cardiopulmonary bypass. Whether the damage can be further reduced by improved intraoperative monitoring and anaesthetic management and better myocardial preservation remains to be determined.

\section{REFERENCES}

I. Lell, W.A., Walker, D.R., Blackstone, E.H., Kouchoukos, N.T., Allarde, R. \& RoE, C.R. Evaluation of myocardial damage in patients undergoing coronary-artery bypass procedures with halothane- $\mathrm{N}_{2} \mathrm{O}$ anesthesia and adjuvants. Anesth. Analg. 56: 556, 1977.

2. Conti, V.R., Bertranou, E.G., Blackstone, E.H., Kirklin, J.W. \& Digerness. S.B. Cold cardioplegia versus hypothermia for myocardial protection. Randomized clinical study. J. Thoracic and Cardiovas. Surg. 76: 577, 1978.

3. Rogers. W.J., MCDaniel, H.G., Smith, L.R., MANTle, J.A., Russell, R.O. \& RaCkley, C.E. Correlation of angiographic estimates of myocardial infarct size and release of creatine kinase $\mathrm{MB}$ isoenzyme in man. Circulation 56: 199, 1977.

4. Barr, A.J., GoOdNight, J.H., SALl, J.P. \& Helwig, J.T. A user's guide to SAS-76. SAS Institute, Inc. Raleigh, North Carolina (1976).

5. Kirklin, J.W., Conti, V.R. \& Blackstone, E. H. Prevention of myocardial damage during cardiac operations. N. Engl. J. Med. 301: 135, 1979.

6. Buckberg, Gerald D. A proposed "solution" to the cardioplegic controversy. J. Thorac. Cardiovas. Surg. 77:803, 1979.

7. Reves, J.G., SAmuelson, P.N., Lell, W.A., AlLARde, R.R., Younes, H.J. \& Oget, O. Anes- 
thesia for coronary artery surgery: An evolution in anesthetic management. Ala. J. Med. Sci. 14: 394, 1977.

8. Merin, R.G., Kumazawa, T., \& Luka, N.L. Myocardial function and metabolism in the conscious dog and during halothane anesthesia. Anesthesiology 44: 402, 1976.

9. Merin, R.G., Kumazawa, T. \& Luka, N.L. Enflurane depresses myocardial function, perfusion and metabolism in the dog. Anesthesiology 45: $501,1976$.

10. BI.AND, J.H.L. \& LowensteIN, E. Halothaneinduced decrease in experimental myocardial ischemia in the non-failing canine heart. Anesthesiology 45: 287-293, 1976.

11. Reves, J.G., Mardis, M.,ERdman, W. \& Karp, R.B. Effects of halothane on normal and ischemic canine myocardial $\mathrm{PO}_{2}$ (Abstract). Annual Meeting of American Society of Anesthesiologists. New Orleans, Louisiana, pp. 253, 1977.

12. Kissin, I., Standeridge, R., Bishop, S.P. \& REVES, J.G. Effect of halothane on myocardial infarct size in rats (Unpublished Results).

13. Gobel, Fredarick L., Nordstrom, L.A., NelSON, R.R., JORGENSEN, C.R. \& WANG, Y. The rate-pressure product as an index of myocardial oxygen consumption during exercise in patients with angina pectoris. Circulation 57: 549, 1978.

14. Wilkinson, Philip L., Moyers, J. R., Ports, T., Chatterjee, K., Ullyott, D. \& Hamilton, W.K. Rate-pressure product and myocardial oxygen consumption during surgery for coronary artery bypass. Circulation 60: I-170, 1979.

15. Reves, J.G., Lell. W.A., McCracken, L.E., Kravetz, R.A. \& Prough, D.S. Comparison of morphine and ketamine anesthetic techniques for coronary surgery: A Randomized Study. South. Med. J. $71: 33,1978$

16. Kistner, J.R., Miller, E.D., LAke, C.L. \& Ross. W.T. Indices of myocardial oxygenation during coronary-artery revascularization in man with morphine versus halothane anesthesia. Anesthesiology $50: 324,1979$.

17. Yakaitis, R.W., BlitT, C.D. \& ANGiulo, J.P. End-tidal enflurane concentration for endotracheal intubation. Anesthesiology 50:59, 1979.

18. Kaplan, J.A. Miller, E.D. \& Bailey, D.R. A comparative study of enflurane and halothane using systolic time intervals. Anesth. Analg. 55: $263,1976$.

19. Bahlman, S.H., Eger, E.I. II, Hal.sey, M.J., Stevens, W.C., Shakespeare, T.F., Smith, N.T., Cromwell. T.H. \& Fourcade, H. The cardiovascular effects of halothane in man during spontaneous ventilation. Anesthesiology 36: 494, 1972
20. Claverley, R.K., Smith, N.T., Phys-Roberts, C., EGer, E.I. Il, \& Jones, C.W. Cardiovascular effects of enflurane anesthesia during controlled ventilation in man. Anesth. Analg. 57: 619, 1978.

21. Reves, J.G., SAMuelson, P.N., Younes, H..l. \& LELL. W.A. Anesthetic considerations for coronary artery surgery. Anes thesiology Review, 4: 19 , 1977.

22. Smith, N.T., Claverley, R.K. Prys-Roberts, C., EgER. E.I. II \& JoNEs, C.W. Impact of nitrous oxide on the circulation during enflurane anesthesia in man. Anesthesiology 48: 345, 1978.

23. Sonntag. H., Donath, U., Hillebrand. W. MERIN, R.G. \& RADKE. J. Left ventricular function in conscious man and during halothane anesthesia. Anesthesiology 48: 320, 1978.

24. Shell, W.E. \& Sobel. B.E. Biochemical markers of ischemic injury. Circulation 53: 1-98, 1976.

25. Roe, C.R., Wagner, G.S., Young, W.G., CurTIS, S.E., СовB, F.R. \& IRviN, R.G. Relation of creatine kinase isoenzyme $M B$ to postoperative electrocardiographic diagnosis in patients undergoing coronary-artery bypass surgery. Clin. Chem. 25: $93,1979$.

26. Gray, R.J., Harris, W.S., Shah, P.K. Miyamoto, A.T.M., Matloff, J.M. \& Swan. H.J.C. Coronary sinus blood flow and sampling for detection of unrecognized myocardial ischemia and injury. Cardiovas. Surg. 56: II-58, 1977.

27. Oldham, H.N. JR., RoE, C.R., Young. W.G. Jr. \& DiXON, S.H. Intraoperative detection of myocardial damage during coronary artery surgery by plasma creatine phosphokinase isoenzyme analysis. Surgery 74: 917, 1973.

28. Isom, O.W., Spencer, F.C., Fejgenbaum, H. Cunningham, C. \& Roe, C. Prebypass myocardial damage in patients underoing coronary revascularization; an unrecognized vulnerable period. Circulation 52: II-119, 1975.

29. Buckburg, G.D., Fixler, D.E., Archer, J.P., et al. Variable effects of heart rate on phasic and regional left ventricular muscle blood flow in anesthetized dogs. Cardiovas Res 9: 1975.

30. Philips, P.A., Marty, A.T. \& Miyamoto, A.M.: A clinical method for detecting subendocardial ischemia after cardiopulmonary bypass. J. Thoracic Cardiovas. Surg. 69: 30, 1975.

31. Hoffman, J.I.E. \& BuckburG, G.D. The myocardial supply-demand ratio: A Critical Review. Am. J. Cardiol. 42: 328, 1978.

32. Fozzard, H.A. \& DAs Gupta, D.S. ST-segment potentials and mapping. Theory and experiments Circulation 54: 533, 1976.

33. Holland, R.P., and Brooks, H. TQ-ST segment mapping: Critical review and analysis of current concepts. Am. J. Cardiol. 40: 110, 1977.

\section{RÉSUMÉ}

Cinquante insuffisants coronariens opérés (pontages aorto-coronariens) ant reçu comme anesthésique principal de l'enflurane (groupe E: 25 cas) ou de l'halothane (groupe H: 25 cas), la sélection de l'agent étant faite au hasard. A l'induction de l'anesthésie, les patients recevaient par voie intraveineuse $0.5 \mathrm{mg} \cdot \mathrm{kg}^{-1}$ de diazepam et $0.1 \mathrm{mg} \cdot \mathrm{kg}^{-1}$ de pancuronium, puis on les ventilait avec un mélange de protoxyde d'azote et d'oxygène à 50 pour cent additionné selon le cas d'halothane ( 0.3 à 0.7 pour cent) ou d'enflurane ( 0.5 à 1.5 pour cent). Les concentrations de ces agents étaient ajustées de façon à maintenir la fréquence cardiaque 
et la pression systolique à l'intérieur de limites prédéterminées. On a comparé chez les patients des deux groupes les dommages myocardiques (critères électrocardiographiques et enzymatiques), les modifications hémodynamiques et les besoins en médication vaso-active.

Un seul patient (du groupe $H$ ) a présenté un infarctus post-opératoire avec manifestations électrocardiographiques et enzymatiques. On n'a pas relevé d'autres manifestations claires d'infarctus à l'électrocardiogramme dans l'un ou l'autre groupe. A l'évaluation du dommage myocardique au moyen des courbes de la $\mathrm{CK} \mathrm{MB}$, on a trouvé des valeurs remarquablement basses et comparables chez les patients des deux groupes. Ainsi, on a trouvé une libération maximale de CK MB (CK MB MAX) de 8.1 $\pm 1 \mathrm{UI} / 1$ chez les patients anesthésiés à l'enflurane et de $7.2 \pm 1.32 \mathrm{UI} / 1$ chez ceux ayant reçu de l'halothane. Le calcul de la surface sous la courbe des CK MB a donné des valeurs de $144 \pm 21.9 \mathrm{UI} / 1 / \mathrm{h}$ pour le groupe $\mathrm{E}$ et de 173 $\pm 32 \mathrm{UI} / 1 / \mathrm{h}$ pour le groupe $\mathbf{H}$. L'évaluation du dommage myocardique à partir de la $\mathrm{CK} \mathrm{MB}$ accumulée (CK MB DS) s'est élevée à $10.5 \pm 1.79$ UI/1 chez les patients anesthẻsiés à l'enflurane et à $10.3 \pm 2.26 \mathrm{UI} / \mathrm{l}$ chez ceux ayant reçu de l'halothane.

Il n'y a pas eu de libération de CK MB avant la CEC chez les patients de l'un et l'autre groupes.

On n’a pas trouvé de différences significatives dans les modifications hémodynamiques observées et dans les besoins en agents vaso-actifs avec l'un etl'autre des anesthésiques, bien qu'on ait observé une tendance à une plus grande utilisation de vasodilatateurs chez les patients anesthésiés à l'halothane.

En conclusion, le taux de dommage myocardique observé après une anesthésie à Thalothane ou à l'enflurane chez le coronarien est bas. La libèration de CK MB est survenue après la $\mathrm{CEC}$ et reflète probablement une protection myocardique imparfaite. Nous n'avons pas étudié les malades présentant une mauvaise fonction ventriculaire; l'halothane et l'enflurane doivent être utilisés judicieusement chez de tels patients. 